\title{
STIMULASI PERKEMBANGAN ANAK MELALUI PERMAINAN TRADISIONAL SUKU BATAK TOBA
}

\author{
Ivo Yani \\ e-mail: ivo.yani@kemdikbud.go.id \\ Balai Pengembangan Pendidikan Anak Usia Dini dan \\ Pendidikan Masyarakat Sumatera Utara
}

\begin{abstract}
Abstrak: Permainan tradisional merupakan warisan leluhur yang perlu dijaga dan dilestarikan. Permainan tradisional jarang sekali dilakukan di PAUD karena sudah tergantikan dengan permainan modern, padahal di setiap daerah terdapat berbagai permainan tradisional. Permainan tradisional suku Batak Toba dapat menstimulasi perkembangan fisik motorik dan sosial emosional anak usia dini. Jenis permainan yang diteliti adalah permainan Marsibahe, Marsitekka, dan Marampera. Penelitian ini bertujuan untuk menemukan hasil stimulasi perkembangan motorik dan sosial-emosional anak usia dini melalui permainan tradisional suku Batak Toba. Penelitian ini dilakukan terhadap 18 anak usia 5- 6 tahun di PAUD Anugerah di Desa Tomok, Kecamatan Simanindo, Kabupaten Samosir pada bulan Juli - Oktober 2015. Instrumen pengumpulan data disusun berdasarkan butir-butir tingkat pencapaian perkembangan motorik dan sosial emosional anak usia 5 - 6 tahun yang mengacu pada Permendikbud No. 137 tahun 2014 sebanyak 16 butir pengamatan. Untuk mengetahui validasi lapangan digunakan metode quasi eksperimen design dengan pretes dan post-test, sedangkan signifikansi program diuji dengan $t$-test berkorelasi. Hasil penelitian menunjukkan bahwa nilai $\mathrm{t}>\mathrm{t} \quad(10,34>2,11)$ sehingga dapat disimpulkan terdapat perbedaan yang signifikan nilai yang diperoleh peserta didik sebelum dengan sesudah melaksanakan permainan tradisional suku Batak Toba pada taraf signifikansi $5 \%$.
\end{abstract}

Kata-kata kunci: stimulasi, permainan tradisional, suku Batak Toba

\section{STIMULATION OF CHILDREN DEVELOPMENT THROUGH BATAK TOBA TRADITIONAL GAMES}

\begin{abstract}
Traditional games are ancestral estates that need to be maintained and preserved. Rarely are they played in PAUD due to the fact that they have been replaced by modern games, whereas there are a lot of traditional games in every region. The Batak Toba traditional games can stimulate both motor skills and social-emotional development in early childhood. Types of games researched are Marsibahe, Marsitekka, and Marampera. This research aims to find out results on motor skills and social-emotional stimulation in early childhood through Batak Toba traditional games. The research was conducted to 18 children in a range of 5-6 years old in PAUD Anugerah in Tomok Village, Simanindo District, Samosir District in July-October 2015. The data collection instrument is arranged based on their achievement levels of motor skills and social-emotional development referring to Permendikbud No. 137 in 2014 as many as 16 points of observation. A quasi-experiment design method with pretest and posttest is used to recognize field validation, meanwhile the significant of the program is examined by using a correlated $t$-test. The results show $t>t(10.34>2.11)$ so that it can be inferred that there are significant changes on score acquired by the learners before and after playing Batak Toba traditional games at $5 \%$ significant level.
\end{abstract}

Keywords: stimulation, traditional game, Batak Toba

\section{PENDAHULUAN}

Pendidikan Anak Usia Dini (PAUD) merupakan upaya pembinaan anak sejak lahir sampai usia 6 tahun yang dilakukan melalui pemberian rangsangan pendidikan untuk membantu pertumbuhan dan perkembangan jasmani dan rohani agar anak memiliki kesiapan dalam memasuki pendidikan 
lebih lanjut (UU No. 20 Tahun 2003 Pasal 1). Masa usia dini merupakan time for play, sebagai sarana pertumbuhan dalam lingkungan, budaya, dan kesiapannya dalam belajar formal. Pada masa ini, pertumbuhan anak sangat menentukan dalam pembentukan karakter dan kecerdasannya. Masamasa ini terpenting bagi pengembangan inteligensi permanen diri anak karena memiliki kemampuan tinggi untuk menyerap informasi. Orang tua dan guru PAUD harus memahami potensi besar yang dimiliki anak pada usia dini dan dapat menggunakan teknik yang tepat dalam menghadapinya.

Bermain merupakan aktivitas yang spontan dan melibatkan motivasi serta prestasi dalam diri anak yang mendalam. Stimulasi perkembangan anak harus selalu dilakukan agar anak dapat mencapai tumbuh kembang sesuai harapan. Melalui bermain, anak belajar untuk mengekspresikan emosi, proses emosi, memodulasi dan mengatur emosi, serta menggunakan emosi dengan cara yang adaptif. Pandangan bermain dan emosi konsisten dengan sejumlah konseptualisasi terbaru dari emosi dan kesehatan mental. Konstruk regulasi emosi sangat penting di daerah perkembangan anak. Mennin dalam Russ (2004) menyimpulkan bahwa perspektif regulasi emosi bertujuan sebagai pengobatan, yakni untuk membantu individu menjadi (a) lebih nyaman dengan membangkitkan pengalaman emosional, (b) lebih mampu mengakses dan memanfaatkan informasi emosional dalam pemecahan masalah adaptif, dan (c) lebih mampu memodulasi pengalaman emosional dan ekspresi.

Latar belakang masalah dalam penelitian ini adalah munculnya berbagai permainan modern yang sangat menarik minat anak, seperti gadget dan fun game lainnya. Anak terlihat asyik bermain di dunia maya secara individual, sehingga tidak memberi kesempatan bagi anak untuk bersosialisasi. Hal ini akan menyebabkan sikap pasif, apatis, dan tidak cekatan menghadapi realitas kehidupan. Jika hal tersebut dibiarkan berlarut-larut, dikhawatirkan dapat menghambat perkembangan motorik kasar pada anak, dan memicu obesitas karena kurang gerak. Selain itu, kemampuan sosial emosional anak tidak berkembang secara optimal karena suka menyendiri. Sebagai pewaris budaya bangsa, sudah selayaknya anak diperkenalkan dengan berbagai permainan tradisional. Kenyataannya, permainan tradisional jarang diterapkan pada pembelajaran PAUD padahal permainan tradisional dapat menstimulasi berbagai perkembangan anak.

Permainan tradisional saat ini sudah jarang ditemukan karena sudah tergantikan dengan permainan modern, padahal permainan tradisional merupakan warisan leluhur dan mudah untuk dilakukan. Selain itu, permainan tradisional banyak manfaatnya dan sangat baik dalam menstimulasi perkembangan anak. Di tanah Batak terdapat berbagai permainan tradisional, seperti marsibahe (lempar batu sambil gendong teman di belakang), margala/marcabor (galasin/gobak sodor), marsitekka (engklek), angker (pecah piring), petor-petor (tembaktembakan) dari pelepah pisang, marjalengkat (engrang), marsabur (kucing-tikus), marcendong (alip cendong), marpukkul (kelereng), marsapelesapele (cublak suweng), marsukke/lukkir (patok lele), marlubang (congklak), marsiadu (serimbang), pat ni gajah (lomba terompa), danggur suri (lempar sisir), cabur (sambar elang), permainan alat musik dari bambu/kayu, dan sebagainya. Sebagian besar permainan tersebut juga terdapat di daerah lain dengan sebutan yang berbeda.

Permainan tradisional selalu dilakukan secara bersama-sama atau berkelompok sehingga dapat menstimulasi kemampuan sosial-emosional anak dan memupuk kerja sama. Anak menjadi lebih realistis, dan siap menerima kekalahan atau memiliki daya juang tinggi untuk meraih kemenangan. Selain itu, permainan tradisional dapat menstimulasi motorik kasar pada anak melalui gerakan-gerakan yang dilakukan sehingga anak lebih tangkas. Permainan tradisional melibatkan seluruh aspek perkembangan seperti motorik, kognitif, bahasa, dan sosial-emosional anak.

Perkembangan fisik-motorik dan sosialemosional sangat perlu distimulasi sejak usia dini karena berdampak pada perkembangan lain, seperti perkembangan nilai agama dan moral, kognitif, bahasa, maupun seni. Stimulasi tersebut tentunya dilakukan melalui kegiatan bermain. Russ (2004) mengungkapkan hasil penelitiannya bahwa kualitas fantasi bermain secara signifikan berhubungan dengan kemampuan untuk menggambarkan pengalaman emosional dan pemahaman tentang emosi orang lain. Kemampuan untuk memahami emosi yang dialami sendiri dan pengalaman orang lain memberikan dasar untuk empati. Kemampuan ini sangat signifikan dengan kemampuan untuk mengendalikan kemampuan verbal.

Model Pembelajaran PAUD dalam 
menstimulasi perkembangan anak melalui permainan tradisional Suku Batak Toba adalah seperangkat kegiatan yang dirancang dalam suatu kegiatan bermain bagi kelompok usia 5-6 tahun dalam mengeksplorasi berbagai permainan tradisional Suku Batak Toba. Program ini bermanfaat untuk menstimulasi kemampuan motorik dan sosial emosional anak, terutama usia 5-6 tahun. Pada usia ini, anak telah mencapai tumbuh kembang yang optimal sesuai perkembangan anak usia dini, baik fisik, sosial-emosional, maupun mentalnya. Anak sudah bisa bekerja sama, mengerti pembicaraan yang menggunakan tujuh kata atau lebih, mengikuti aturan permainan, dan mampu mengelola emosinya. Karena berbagai keterbatasan, maka rumusan masalah dalam penelitian ini adalah bagaimana program pembelajaran PAUD melalui permainan tradisional Suku Batak Toba dalam menstimulasi perkembangan anak? sedangkan jenis permainan yang diteliti ada sebanyak tiga jenis, yaitu marsibahe, marsitekka, dan marampera. Pemilihan jenis permainan ini berdasarkan kemampuan anak usia 5-6 tahun dalam melakukan permainan.

Tujuan penelitian ini adalah (1) menggali dan memperkenalkan permainan tradisional kepada anak sejak dini; (2) mengumpulkan data, fakta, atau informasi mengenai stimulasi perkembangan anak melalui permainan tradisional Suku Batak Toba; serta (3) mengetahui seberapa besar permainan tradisional Suku Batak Toba dapat menstimulasi pencapaian perkembangan anak sedangkan manfaat penelitian ini adalah (1) memupuk rasa cinta tanah air dan kebudayaan daerah; (2) melatih kemampuan fisik, memupuk kerja sama, meningkatkan kepercayaan diri memahami konsep sportivitas, belajar mengelola emosi, menggali kreativitas, dan bersosialisasi; serta (3) memperluas wawasan guru PAUD dalam menstimulasi perkembangan fisik motorik dan sosial emosional anak usia dini.

Untuk mendukung dan memperkuat pembahasan pada penelitian ini, terdapat beberapa teori yang digunakan sebagai rujukan penelitian.

\section{Pengertian Pembelajaran pada Pendidikan Anak} Usia Dini

Usia dini adalah masa ketika anak menghabiskan sebagian besar waktunya untuk bermain. Oleh sebab itu, pembelajaran anak usia dini harus berpusat pada anak dengan menggunakan prinsip belajar melalui bermain. Pembelajaran pada PAUD dilaksanakan melalui bermain dan kegiatan- kegiatan yang mengandung prinsip bermain. Mayke dalam Sudono (2000) menyatakan bahwa belajar dengan bermain memberi kesempatan kepada anak untuk memanipulasi, mengulang-ulang, menemukan sendiri, bereksplorasi, mempraktikkan, dan mendapatkan bermacam-macam konsep serta pengertian yang tidak terhitung banyaknya. Melalui hal tersebut, terjadilah proses pembelajaran anak dapat mengambil keputusan, memilih, menentukan, mencipta, memasang, membongkar, mengembalikan, mencoba, mengeluarkan pendapat, memecahkan masalah, mengerjakan secara tuntas, bekerjasama dengan teman, dan mengelola berbagai macam perasaan. Oleh karena itu, satuan PAUD harus mampu memfasilitasi kebutuhan bermain anak agar stimulasi perkembangannya optimal.

Mulyani, dkk (2005) menyatakan bahwa perkembangan anak adalah tahapan-tahapan penting yang dicapai anak akibat pertumbuhan dan proses belajar dalam hidupnya, yang antara lain meliputi perkembangan fisik, kognitif (mental), bahasa, serta sosial dan emosional. PAUD merupakan salah satu jenjang pendidikan yang memiliki peran strategis dalam proses pendidikan secara keseluruhan karena merupakan landasan dan wahana penyiapan anak untuk memasuki pendidikan dasar, oleh karena itu, PAUD harus memperoleh perhatian yang memadai. PAUD berfungsi membina, menumbuhkan, dan mengembangkan seluruh potensi anak usia dini secara optimal yang dilakukan melalui kegiatan bermain, sehingga terbentuk perilaku dan kemampuan dasar sesuai dengan tahap perkembangannya agar memiliki kesiapan untuk memasuki pendidikan selanjutnya.

Dalam Lampiran IV Peraturan Menteri Pendidikan dan Kebudayaan Republik Indonesia Nomor 146 Tahun 2014 tentang Kurikulum 2013 PAUD dinyatakan bahwa pembelajaran adalah proses interaksi antara pendidik dengan anak melalui kegiatan bermain pada lingkungan belajar yang aman dan menyenangkan dengan menggunakan berbagai sumber belajar. Dalam bermain, anak membuat pilihan, memecahkan masalah, berkomunikasi, dan bernegosiasi. Anak menciptakan peristiwa khayalan, melatih keterampilan fisik, sosial, dan kognitif. Ketika bermain, anak dapat mengekspresikan dan melatih emosi dari pengalaman dan kejadian yang ditemui setiap hari. Melalui kegiatan bermain bersama dan mengambil peran berbeda, anak mengembangkan kemampuan melihat sesuatu dari sudut pandang 
orang lain dan terlibat dalam perilaku pemimpin atau pengikut. Perilaku ini sangat diperlukan saat bergaul ketika dewasa.

Menurut teori kelebihan energi yang diungkapkan oleh Herbert Spencer dalam Montolalu (2010), bermain dipandang sebagai penutup atau klep keselamatan pada mesin uap. Energi atau tenaga yang berlebih pada anak perlu dibuang atau dilepaskan melalui bermain. Bermain merupakan bentuk pelepasan energi yang berlebih pada anak sehingga perlu dibuang agar anak lebih memiliki kesiapan menerima materi pembelajaran. Melalui bermain, energi yang berlebih pada anak tidak digunakan untuk hal-hal yang bersifat destruktif, misalnya merusak alat dan bahan main. Bentuk bermain yang penting untuk tetap dipertahankan adalah permainan tradisional karena mengandung unsur edukasi dan berakar dari budaya bangsa.

Montessori dalam Sudono (2000), menekankan bahwa ketika anak bermain, akan mempelajari dan menyerap segala sesuatu yang terjadi di lingkungan sekitarnya. Dalam pendidikan anak usia dini, bermain identik dengan belajar, karena melalui bermain, anak memahami pengertian atau konsep-konsep melalui benda-benda konkret. Belajar melalui bermain memberi kesempatan kepada anak untuk memanipulasi, mengulang-ulang, menemukan sendiri, bereksplorasi, mempraktikkan, dan memperoleh bermacam-macam konsep serta pengertian yang tidak terhitung banyaknya.

Pengertian pembelajaran pada penelitian ini adalah kegiatan bermain yang dilakukan melalui permainan tradisional Suku Batak Toba dengan sasaran anak usia 5-6 tahun. Sebagaimana diungkapkan Sudono (2000), ciri-ciri anak usia 5-6 tahun antara lain (a) gerakan lebih tangkas, (b) berjalan dan melangkah lebih tegap, (c) berdiri dengan satu kaki lebih dari 8 detik, (d) lari berjingkat dengan dua kaki bergantian, (e) dapat mengatur keseimbangan tubuh, $(f)$ bermain dengan kelompok dua sampai lima orang teman, (g) bekerjanya terpacu oleh kompetisi dengan anak lain, dan (h) dapat mendengarkan instruksi.

\section{Stimulasi Perkembangan Anak}

Upaya menciptakan lingkungan yang mendukung tercapainya prestasi perkembangan anak dapat dilakukan melalui kegiatan bermain, karena dunia anak adalah dunia bermain. Sebagaimana diungkapkan Sudono (2000), bermain adalah suatu kegiatan yang dilakukan dengan atau tanpa menggunakan alat yang menghasilkan pengertian atau memberikan informasi, memberi kesenangan, maupun mengembangkan imajinasi anak.

Lingkup perkembangan sesuai tingkat usia anak meliputi aspek nilai agama dan moral, fisikmotorik, kognitif, bahasa, sosial-emosional, dan seni. Dalam pengembangan ini, lingkup perkembangan dibatasi perkembangan fisik-motorik dan sosialemosional. Perkembangan fisik-motorik meliputi motorik kasar dan halus. Motorik kasar mencakup kemampuan gerakan tubuh secara terkoordinasi, lentur, seimbang, lincah, lokomotor, non-lokomotor, dan mengikuti aturan. Motorik halus mencakup kemampuan dan kelenturan menggunakan jari dan alat untuk mengeksplorasi dan mengekspresikan diri dalam berbagai bentuk. Perkembangan sosialemosional meliputi (a) kesadaran diri yang terdiri dari memperlihatkan kemampuan diri, mengenal perasaan sendiri dan mengendalikan diri, serta mampu menyesuaian diri dengan orang lain; (b) rasa tanggung jawab untuk diri dan orang lain, mencakup kemampuan mengetahui hak-haknya, mentaati aturan, mengatur diri sendiri, serta bertanggung jawab atas perilakunya untuk kebaikan sesama; dan (c) perilaku prososial yang mencakup kemampuan bermain dengan teman sebaya, memahami perasaan, merespon, berbagi, serta menghargai hak dan pendapat orang lain, bersikap kooperatif, toleran, dan berperilaku sopan.

Berdasarkan uraian di atas, stimulasi perkembangan anak pada penelitian ini adalah rangsangan yang diberikan pada anak melalui permainan tradisional Suku Batak Toba untuk mencapai perkembangan fisik-motorik dan sosialemosional anak usia 5-6 tahun.

\section{Permainan Tradisional Suku Batak Toba}

Anak adalah pewaris budaya bangsa yang kreatif, karenanya pendidik harus mampu memberi rangsangan pendidikan atau stimulasi sesuai kebutuhan anak dengan cara mengembangkan kemampuan sebagai pewaris budaya bangsa yang kreatif dan peduli terhadap permasalahan masyarakat dan bangsa. Salah satu stimulasi yang dapat dilakukan adalah melalui permainan tradisional. Pada hakikatnya, bermain bagi anak usia dini merupakan proses pembelajaran, untuk itu dibutuhkan media yang mampu menstimulasi perkembangan anak melalui berbagai permainan tradisional.

Menurut Wikipedia bahasa Indonesia, 
permainan merupakan sebuah aktivitas rekreasi dengan tujuan bersenang-senang, mengisi waktu luang, atau berolahraga ringan. Permainan biasanya dilakukan sendiri atau bersama-sama (kelompok) sedangkan tradisional adalah segala sesuatu yang dituturkan atau diwariskan secara turun temurun dari orang tua atau nenek moyang. Jadi, permainan tradisional bisa diartikan sebagai perbuatan (baik menggunakan alat atau tidak) yang diwariskan secara turun temurun dari nenek moyang, sebagai sarana hiburan atau untuk menyenangkan hati.

Permainan tradisional memiliki fungsi rekreatif, kompetitif, dan edukatif. Permainan tradisional yang bersifat rekreatif dilakukan untuk mengisi waktu luang. Permainan tradisional yang bersifat kompetitif (untuk bertanding) memiliki aturan tertentu (terorganisir) sebagai kriteria pemenang, dimainkan secara beregu (minimal 2 orang per regu), dan mempunyai kriteria yang menentukan siapa yang menang dan kalah. Permainan tradisional yang bersifat edukatif, mengandung unsur-unsur pendidikan di dalamnya. Anak-anak diperkenalkan dengan berbagai macam keterampilan dan kecakapan yang nantinya akan diperlukan dalam menghadapi kehidupan sebagai anggota masyarakat. Permainan jenis ini menjadi alat sosialisasi untuk anak-anak agar dapat menyesuaikan diri sebagai anggota kelompok sosialnya.

Permainan tradisional memang terkesan sederhana, namun di balik itu sebenarnya permainan tradisional memiliki manfaat yang baik untuk perkembangan pertumbuhan anak. Banyak hal yang diperoleh anak dari sebuah permainan tradisional melalui proses bermain, karena anak terlibat secara langsung baik fisik maupun emosi sehingga dapat mempengaruhi pertumbuhannya.
Dalam penelitian ini, manfaat utama yang akan dikaji dari permainan tradisional yang akan diteliti adalah untuk menstimulasi kemampuan motorik dan sosialemosional anak usia 5-6 tahun.

Permainan tradisional umumnya dilakukan secara berkelompok, sehingga permainan ini otomatis mengajarkan kebersamaan. Dalam permainan kelompok, anak membutuhkan teman kelompok yang berarti memberi kesempatan pada anak untuk bersosialisasi. Selain kebersamaan, anak diajarkan untuk berempati, bergiliran, menaati peraturan, juga solidaritas. Selain itu, anak akan dilatih kekompakannya dalam menyusun strategi agar dapat memenangkan permainan. Aktivitas fisik yang dilakukan anak ketika bermain secara langsung merangsang gerakan motorik anak, baik motorik halus seperti menggambar, meremas, menggenggam, maupun motorik kasar seperti melompat, berlari, berjongkok, dan meloncat. Selain itu, bermain juga berfungsi untuk melatih dan mengembangkan gerakan otot pada anak, contohnya dalam permainan marsitekka, permainan ini mendukung pertumbuhan anak terutama kecerdasan kinetiknya. Ketika bermain, anak melompat dengan satu kaki sehingga akan berusaha untuk menyeimbangkan tubuhnya dan lompatan yang dilakukan juga baik bagi metabolisme tubuh. Hampir semua permainan tradisional dilakukan secara berkelompok. Melalui kegiatan berkelompok anak akan merasa nyaman dan terbiasa dalam kelompok, dapat memupuk rasa setia kawan, mengatur emosinya sehingga timbul toleransi dan empati terhadap orang lain, mengembangkan sikap bekerjasama dengan kawan, serta memupuk sikap sportif sejak dini.

\section{METODE PENELITIAN}

Penelitian ini dilakukan di PAUD Anugerah

Desa Tomok Kecamatan Simanindo Kabupaten Samosir pada minggu ke-4 Juli sampai dengan minggu ke-5 Oktober 2015. Dilihat dari tujuannya, penelitian ini termasuk penelitian deskriptif dengan menggunakan perhitungan statistik sederhana untuk mengetahui capaian perkembangan fisik-motorik dan sosial-emosional anak pada saat sebelum dan sesudah penelitian. Penelitian ini menggunakan metode quasi eksperimen design dengan pre-test dan post-test: 01 X 02 .

\section{Keterangan: $\mathrm{O}_{1}$ : Pre-test \\ $\mathrm{X}$ : Perlakuan \\ $\mathrm{O}_{2}$ : Post-test}

Untuk mengetahui tingkat efektivitas program dilakukan dengan analisis kuantitatif. Data yang dikumpul dianalisis dengan menggunakan statistik sederhana dengan menentukan rata-rata kelas sebagai daya serap klasikal. Untuk mengetahui signifikansi program di uji dengan t-test berkorelasi.

Populasi dalam penelitian ini adalah anak usia dini 3-6 tahun berjumlah 33 orang sedangkan 
sampelnya adalah anak usia 5-6 tahun berjumlah 18 orang. Teknik pengumpulan data dilakukan dengan pendekatan kualitatif dan kuantitatif. Dalam pendekatan kualitatif, data dikumpulkan dengan cara observasi/mengunjungi langsung ke lokasi dan mencatat temuan-temuan lapangan. Kemudian melakukan diskusi terfokus. Data/informasi yang diperlukan diperoleh dengan menggunakan beberapa instrumen, yaitu instrumen monitoring untuk memperoleh informasi tentang penyelenggaraan program, instrumen penelitian untuk memperoleh informasi tentang kondisi objektif yang terjadi pada saat proses pembelajaran berlangsung, dan instrumen observasi untuk memperoleh informasi tentang interaksi dalam pembelajaran.

Selain itu, dilakukan juga teknik dokumentasi yang dimaksudkan untuk melengkapi data dari observasi. Teknik dokumentasi digunakan untuk mengumpulkan data dari sumber noninsani yang berupa dokumen-dokumen administrasi, gambar/ foto atau catatan-catatan lain yang berhubungan dengan fokus penelitian. Selain itu, data dan informasi digali melalui studi dokumen di berbagai perpustakaan dan lembaga/instansi yang memiliki data dan informasi terkait dengan pengembangan program.

Berbagai data/informasi yang ditemukan dianalisis dengan metode induktif, artinya berbagai data/informasi mula-mula dianalis dari yang khusus menuju ke yang umum. Analisis ini dapat diartikan pula menganalisis data/informasi dari yang kecil menuju ke yang besar. Setiap temuan akan dimaknai sehingga benar-benar berarti.

\section{PEMBAHASAN}

\section{Hasil}

Hasil penelitian diperoleh melalui pengamatan selama perlakuan program yang meliputi penyelenggaraan program dan pencapaian perkembangan fisik-motorik dan sosial-emosional anak yang dilakukan selama kurang lebih 3 bulan. Setiap datang ke lokasi penelitian, temuan-temuan dicatat sesuai dengan instrumen yang telah disiapkan, terdiri dari instrumen monitoring dan evaluasi serta instrumen pengamatan perkembangan fisik-motorik dan sosial-emosional anak usia 5-6 tahun.

\section{Pengamatan terhadap penyelenggaraan program}

Pengamatan terhadap penyelenggaraan program seperti terlihat pada Tabel 1.

Tabel 1

Hasil Penyelenggaraan Program

\begin{tabular}{|c|c|c|c|}
\hline No. & Komponen & Indikator & Hasil \\
\hline 1. & $\begin{array}{l}\text { Peserta } \\
\text { didik }\end{array}$ & $\begin{array}{l}\text { a. Ketepatan } \\
\text { jumlah } \\
\text { b. Kesesuain } \\
\text { persyaratan } \\
\text { c. Persentase } \\
\text { kehadiran peserta }\end{array}$ & $\begin{array}{l}\text { Dari segi peserta didik dapat di- } \\
\text { katakan sesuai dengan persyaratan } \\
\text { yang diharapkan dimana jumlah } \\
\text { peserta didik khususnya yang dike- } \\
\text { nakan perlakuan (usia } 5-6 \text { ) tahun } \\
\text { yang berjumlah } 18 \text { orang memenuhi } \\
\text { persyaratan dan persentase ke- } \\
\text { hadiran mencapai lebih dari } 90 \% \text {. }\end{array}$ \\
\hline 2. & Pendidik & $\begin{array}{l}\text { a. Kesesuaian per- } \\
\text { syaratan pendidik } \\
\text { b. Kehadiran } \\
\text { c. Aktvitas pendidik }\end{array}$ & $\begin{array}{l}\text { Pendidik yang melaksanakan keg- } \\
\text { iatan permainan tradisional ini sudah } \\
\text { memenuhi persyaratan dengan kuali- } \\
\text { fikasi: } 2 \text { orang S1 PAUD dan } 1 \text { orang } \\
\text { SMA. Aktivitas pendidik juga sangat } \\
\text { baik, mereka hadir setiap hari ( } 100 \%) \\
\text { serta aktif membimbing anak agar } \\
\text { mampu melakukan permainan sesuai } \\
\text { dengan aturan yang ditetapkan meski- } \\
\text { pun awalnya mengalami kesulitan. }\end{array}$ \\
\hline
\end{tabular}

\begin{tabular}{|c|c|c|c|}
\hline No. & Komponen & Indikator & Hasil \\
\hline 3. & Pengelola & $\begin{array}{l}\text { a. Kesesuaian } \\
\text { persyaratan } \\
\text { pengelola } \\
\text { b. Kehadiran } \\
\text { c. Aktvitas } \\
\quad \text { pengelola }\end{array}$ & $\begin{array}{l}\text { Pengelola berpendidikan } \mathrm{S} 1 \text { kependi- } \\
\text { dikan, selalu memberikan dukungan } \\
\text { positif dalam pelaksanaan program } \\
\text { serta selalu mau bekerjasama dengan } \\
\text { tim pengembangan dan pendidik } \\
\text { dalam menyiapkan sarana prasarana } \\
\text { pendukung. Aktivitas pengelola juga } \\
\text { aktif membantu pendidik di lapangan. }\end{array}$ \\
\hline 4. & $\begin{array}{l}\text { Admin- } \\
\text { istrasi } \\
\text { Kelompok } \\
\text { Belajar }\end{array}$ & $\begin{array}{l}\text { Daftar hadir: } \\
\text { a. anak } \\
\text { b. pendidik } \\
\text { c. Jadwal kegiatan } \\
\text { d. Bahan ajar }\end{array}$ & $\begin{array}{l}\text { Administrasi kelompok belajar ma- } \\
\text { sih butuh perbaikan dan dukungan } \\
\text { dalam hal jadwal kegiatan dan bahan } \\
\text { ajar. Untuk administrasi daftar hadir } \\
\text { peserta didik dan pendidik sudah baik. }\end{array}$ \\
\hline 5. & $\begin{array}{l}\text { Tempat } \\
\text { Belajar }\end{array}$ & $\begin{array}{l}\text { a. Kenyamanan } \\
\text { b.Penerangan dan } \\
\text { fasilitas air bersih }\end{array}$ & $\begin{array}{l}\text { Untuk tempat belajar sudah memenuhi } \\
\text { kriteria tempat belajar yang nya- } \\
\text { man dan memiliki penerangan dan } \\
\text { fasilitas air bersih yang cukup baik. }\end{array}$ \\
\hline 6. & $\begin{array}{l}\text { Sarana } \\
\text { Belajar }\end{array}$ & $\begin{array}{l}\text { a. Perbandingan } \\
\text { sarana dengan } \\
\text { peserta didik } \\
\text { b. Kesesuaian } \\
\text { sarana }\end{array}$ & $\begin{array}{l}\text { Perbandingan sarana dengan peser- } \\
\text { ta didik masih belum sebanding. } \\
\text { Sarana masih perlu ditambah, un- } \\
\text { tuk itu pengembangan memberikan } \\
\text { bantuan sarana agar dapat mem- } \\
\text { bantu pengelola melengkapi sara- } \\
\text { na yang dibutuhkan peserta didik. }\end{array}$ \\
\hline 7. & $\begin{array}{l}\text { Program } \\
\text { Belajar }\end{array}$ & $\begin{array}{l}\text { a. Kesesuaian: } \\
\text { jadwal } \\
\text { b. Kesesuaian } \\
\text { metode } \\
\text { c. Instrumen } \\
\text { penilaian }\end{array}$ & $\begin{array}{l}\text { Untuk program belajar sudah sesuai } \\
\text { dan metode yang digunakan juga } \\
\text { sudah sesuai yaitu belajar melalui } \\
\text { bermain. Dalam hal instrumen penilaian } \\
\text { masih butuh penguatan karena secara } \\
\text { umum lembaga belum memilikinya }\end{array}$ \\
\hline 8. & $\begin{array}{l}\text { Ragi } \\
\text { Belajar }\end{array}$ & Lomba antar regu & $\begin{array}{l}\text { Ragi belajar diberikan dalam bentuk } \\
\text { pujian dan lomba antar regu. Sesekali } \\
\text { diberikan hadiah berupa makanan. }\end{array}$ \\
\hline 9. & $\begin{array}{l}\text { Dana } \\
\text { Belajar }\end{array}$ & $\begin{array}{l}\text { a. Sumber dana } \\
\text { b. Alokasi dana }\end{array}$ & $\begin{array}{l}\text { Sumber dana kegiatan berasal dari uang } \\
\text { iuran peserta didik dan bantuan dari pi- } \\
\text { hak lain yang tidak mengikat. Alokasi } \\
\text { dana ditujukan untuk insentif pendidik, } \\
\text { pengelola dan biaya insidental lainnya }\end{array}$ \\
\hline 10. & $\begin{array}{l}\text { Hasil } \\
\text { Belajar }\end{array}$ & $\begin{array}{l}\text { a. Program terse- } \\
\text { lenggara } \\
\text { b. } 80 \% \text { peserta } \\
\text { aktif }\end{array}$ & $\begin{array}{l}\text { Hasi belajar sangat baik dimana } \\
\text { semua stakeholder memberikan du- } \\
\text { kungan dan peserta sangat aktif } \\
\text { hinga lebih dari } 90 \% \text { partisipasi aktif }\end{array}$ \\
\hline
\end{tabular}


Tabel 1 menunjukkan bahwa pada komponen peserta didik terdapat kesesuaian jumlah peserta didik yakni 18 orang, kesesuaian persyaratan peserta didik yakni usia 5-6 tahun, dan tingkat kehadiran peserta didik yakni $90 \%$. Hal ini sangat penting untuk melihat konsistensi peserta didik dari segi jumlah, usia, dan kehadiran. Komponen pendidik menunjukkan adanya kesesuaian persyaratan pendidik yakni minimal 1 orang pendidik berkualifikasi S1 PAUD, kehadiran minimal $90 \%$, dan aktif dalam melakukan stimulasi pada peserta didik. Komponen pengelola memiliki kesesuaian persyaratan yakni minimal berkualifikasi SLTA, hadir setiap hari dan mendukung terlaksananya stimulasi.

Untuk komponen administrasi, tersedia daftar hadir peserta didik, guru, dan pengelola namun jadwal stimulasi tidak dilakukan setiap hari. Panduan-panduan untuk permainan tradisional juga masih minim. Komponen tempat belajar sangat mendukung terselenggaranya permainan tradisional. Sementara sarana permainan tidak mencukupi untuk semua anak, sehingga ada yang bergantian melakukan permainan. Jika semua anak bisa setiap hari melakukan permainan tradisional dan peralatan main lengkap, tentu hasilnya akan lebih maksimal. Komponen program belajar menunjukkan kesesuaian jadwal dan metode belajar namun instrumen penilaian belum lengkap.

Pada komponen ragi belajar, dilakukan lomba antarregu. Komponen dana belajar menunjukkan bahwa penggunaan dana masih berkisar pada kebutuhan pokok yaitu gaji guru dan pengelola, untuk memenuhi kebutuhan akan permainan tradisional belum semuanya terpenuhi. Komponen hasil belajar menunjukkan hasil yang sangat baik karena $>90 \%$ anak mau dan berhasil melakukan permainan tradisional.

Hasil pengamatan terhadap perkembangan anak

Pengumpulan data pengamatan perkembangan fisik-motorik dan sosial-emosional untuk setiap anak menggunakan instrumen yang mengacu pada Permendikbud No. 137 tahun 2014 sebanyak 16 butir pengamatan yang memuat capaian perkembangan seperti terlihat pada Tabel 2 . Tabel 2

\begin{tabular}{ll} 
Capaian Perkembangan Anak \\
\hline No. & \multicolumn{1}{c}{ Capaian Perkembangan } \\
\hline 1. & $\begin{array}{l}\text { Melakukan gerakan tubuh secara terkoordinasi untuk melatih kelenturan, } \\
\text { keseimbangan, dan kelincahan }\end{array}$ \\
2. & Melakukan permainan fisik dengan aturan \\
3. & Terampil menggunakan tangan kanan dan kiri \\
\hline
\end{tabular}

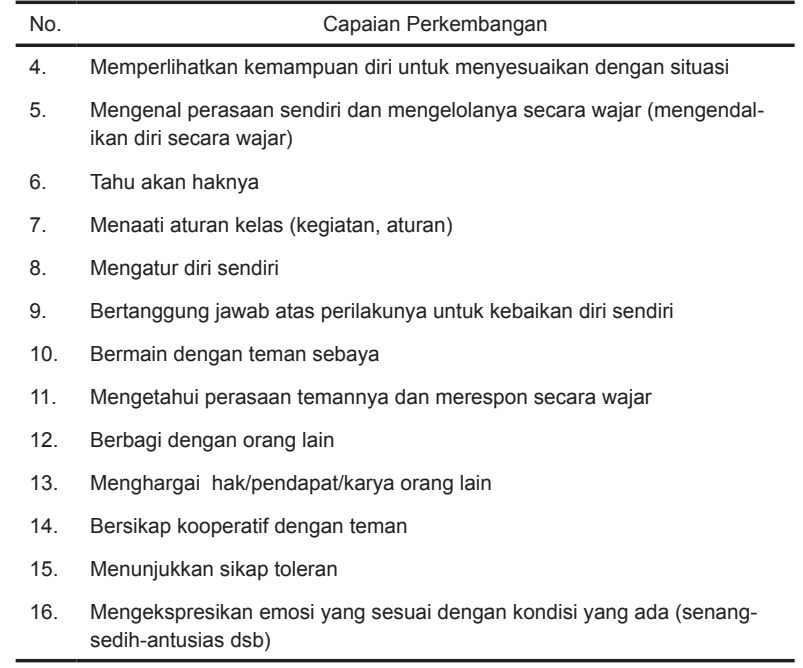

Pengamatan dilakukan sebelum (pre-test) dan sesudah (post-test) melakukan permainan tradisional dengan rentang skor berikut (1) skor 1: Belum Berkembang (BB); (2) skor 2: Mulai Berkembang (MB); (3) Skor 3: Berkembang Sesuai Harapan (BSH); dan (4) Skor 4: Berkembang Sangat Baik (BSB).

Stimulasi melalui permainan tradisional Marsibahe dapat dilihat bahwa skor pre-test terendah adalah 1,9 dan tertinggi adalah 3,3 , sedangkan skor post-test terendah adalah 2,1 dan tertinggi 3,4. Hasil analisis terhadap pencapaian perkembangan fisik-motorik dan sosial-emosional anak usia 5-6 tahun sebanyak 18 orang yang distimulasi melalui permainan tradisional Marsibahe terlihat adanya peningkatan skor rata-rata pre-test dan post-test dari 2,4 menjadi 2,7 atau $12,5 \%$.

Untuk stimulasi melalui permainan tradisional Marsitekka dapat dilihat bahwa skor pre-test terendah adalah 2,0 dan tertinggi adalah 3,3, sedangkan skor post-test terendah adalah 2,3 dan tertinggi 3,4. Hasil analisis terhadap pencapaian perkembangan fisik-motorik dan sosial-emosional anak usia 5-6 tahun sebanyak 18 orang yang distimulasi melalui permainan tradisional Marsitekka terlihat adanya peningkatan skor rata-rata pre-test dan post-test dari 2,4 menjadi 2,7 atau $12,5 \%$.

Untuk stimulasi melalui permainan tradisional Marampera dapat dilihat bahwa skor pre-test terendah adalah 1,9 dan tertinggi adalah 3,3, sedangkan skor post-test terendah adalah 2,2 dan tertinggi 3,4 . Hasil analisis terhadap pencapaian perkembangan fisik motorik dan sosial emosional anak usia 5-6 tahun sebanyak 18 orang yang distimulasi melalui permainan tradisional Marsibahe 
terlihat adanya peningkatan skor rata-rata pre-test dan post-test dari 2,4 menjadi 2,7 atau $12,5 \%$.

Data di atas menunjukkan bahwa capaian perkembangan setiap anak berbeda-beda namun secara umum untuk ketiga jenis permainan hampir sama bahkan memiliki rata-rata sama, baik nilai pretest $(2,4)$ maupun post-test $(2,7)$. Berdasarkan data pencapaian perkembangan fisik-motorik dan sosialemosional anak di atas, dapat diketahui signifikansi program dengan melakukan uji t-test berkorelasi (dependent sample).

Derajat kebebasan ( $\mathrm{dk}$ ) adalah $=\mathrm{n}-1=$ $18-1=17$. Nilai ini dikonfirmasi ke dalam daftar Distribusi t dengan taraf signifikansi $5 \%$ dan terlihat $t=2,11$. Pada taraf signifikansi 0,05 terlihat nilai $t>t \quad(10,34>2,11)$ sehingga dapat disimpulkan bahwa terdapat perbedaan yang signifikan nilai yang diperoleh peserta didik sebelum dengan sesudah melaksanakan permainan tradisional suku Batak Toba pada taraf signifikansi $5 \%$.

\section{Pembahasan}

Hasil penelitian ini telah membuktikan secara signifikan bahwa terdapat perbedaan yang signifikan nilai yang diperoleh peserta didik sebelum dengan sesudah melaksanakan permainan tradisional suku Batak Toba pada taraf signifikansi $5 \%$, terlihat dari nilai $\mathrm{t}>\mathrm{t}(10,34>2,11)$.

Hasil capaian perkembangan anak setelah mendapat stimulasi dengan permainan tradisional suku Batak Toba lebih tinggi dari sebelum stimulasi. Hal ini sesuai dengan pernyataan Montessori dalam Sudono (2000) yang menekankan bahwa ketika anak bermain, akan mempelajari dan menyerap segala sesuatu yang terjadi di lingkungan sekitarnya sehingga mampu melakukan permainan tradisional dengan baik. Berikut akan dideskripsikan stimulasi perkembangan anak melalui permainan tradisional suku Batak Toba.

Permainan marsibahe dilakukan secara beregu dengan menggendong teman di punggung secara bergantian. Kegiatan ini melatih otot kaki dan tulang punggung anak sehingga dapat melakukan gerakan tubuh secara terkoordinasi untuk melatih kelenturan, keseimbangan, dan kelincahan. Hal ini sesuai dengan ungkapan Sudono (2000), bahwa ciriciri anak usia 5-6 tahun antara lain (a) gerakan lebih tangkas, (b) berjalan dan melangkah lebih tegap, (c) dapat mengatur keseimbangan tubuh, (d) bermain berkelompok dengan dua sampai lima orang teman, serta (e) bekerjanya terpacu oleh kompetisi, selain itu juga memberi alternatif pilihan dalam menggendong atau memikul benda yang berat.

Sebelum melakukan permainan, pendidik dan peserta didik membuat aturan main sehingga anak terbiasa melakukan permainan fisik dengan aturan. Ketika melempar kayu (gacok), anak dapat menggunakan tangan kanan atau kiri secara bergantian yang bertujuan agar anak terampil menggunakan tangan kanan dan kiri. Hal ini memperlihatkan kemampuan diri untuk menyesuaikan dengan situasi.

Melalui permainan marsibahe, anak mengenal perasaan sendiri dan mengelolanya secara wajar (mengendalikan diri secara wajar), hal ini terjadi ketika anak mendapat giliran untuk menggendong temannya. Anak menjadi tahu akan haknya sehingga terstimulasi untuk menaati aturan main dan hal ini membiasakan anak untuk menaati aturan kelas, dengan demikian, anak akan bertanggung jawab atas perilakunya untuk kebaikan diri sendiri dan bermain dengan teman sebayanya. Hal ini sesuai dengan pernyataan Montessori dalam Sudono (2000) yang menekankan bahwa ketika anak bermain, akan mempelajari dan menyerap segala sesuatu yang terjadi di lingkungan sekitarnya.

Permainan marsibahe juga dapat menstimulasi perilaku anak untuk menghargai hak/pendapat orang lain dan bersikap kooperatif dengan teman sehingga dapat mengekspresikan emosi yang sesuai dengan kondisi yang ada (senang, sedih, antusias, dan sebagainya).

Permainan marsitekka merupakan permainan yang dilakukan secara perorangan dengan melompati kotak-kotak pola secara berurutan menggunakan satu kaki (engklek). Hal ini sesuai dengan ungkapan Sudono (2000), bahwa ciri-ciri anak usia 5-6 tahun antara lain (a) gerakan lebih tangkas, (b) berjalan dan melangkah lebih tegap, (c) berdiri dengan satu kaki lebih dari 8 detik, (d) dapat mengatur keseimbangan tubuh, (e) bermain dengan kelompok dua sampai lima orang teman, serta (f) bekerjanya terpacu oleh kompetisi.

Sebelum melakukan permainan, pendidik dan peserta didik membuat aturan main sehingga anak terbiasa melakukan permainan fisik dengan aturan. Kegiatan ini menggunakan satu kaki, sehingga dapat melatih anak untuk melakukan gerakan tubuh secara terkoordinasi untuk melatih kelenturan, keseimbangan, dan kelincahan. Anak dapat menggunakan tangan kanan atau kiri ketika 
melempar dan mengambil ucak (gacok), hal ini melatih anak untuk terampil menggunakan tangan kanan dan kiri.

Selain kemampuan-kemampuan fisik-motorik di atas, permainan marsitekka dapat menstimulasi sosial-emosional anak. Hal ini terlihat ketika anak menunjukkan kemampuan dirinya untuk menyesuaikan dengan situasi pada saat menunggu giliran bermain. Apabila anak melanggar aturan main, misalnya ketika menginjak garis, anak harus berganti dengan lawannya disertai rasa kecewa. Hal ini membuat anak terlatih mengenal perasaan sendiri dan mengelolanya secara wajar (mengendalikan diri secara wajar). Sebagaimana ungkapan Carolyn Triyon dan J.W Liliental dalam Moeslichatun (2004) bahwa tugas-tugas perkembangan masa kanak-kanak awal yang harus dijalani anak usia dini di antaranya mengembangkan pengendalian diri untuk bertingkah laku sesuai dengan tuntutan masyarakatnya.

Anak belajar untuk memahami bahwa setiap perbuatan memiliki konsekuensi atau akibat. Anak yang mendapat giliran main mengetahui akan haknya untuk melakukan giliran main, dengan demikian, anak mentaati aturan dalam kegiatan main dan bertanggung jawab atas perilakunya untuk kebaikan diri sendiri dalam bermain dengan teman sebaya. Hal ini dapat menstimulasi anak untuk menghargai hak/pendapat orang lain, dan mengekspresikan emosi yang sesuai dengan kondisi yang ada (senang, sedih, antusias, dan sebagainya).

Permainan marampera menggunakan karet gelang yang disambung-sambung hingga panjang seperti tali. Permainan ini dapat dilakukan beregu dan dapat pula perorangan. Sebagaimana diungkapkan Sudono (2000), ciri-ciri anak usia 5-6 tahun antara lain (a) gerakan lebih tangkas, (b) berjalan dan melangkah lebih tegap, (c) lari berjingkat dengan dua kaki bergantian, (d) bermain dengan kelompok dua sampai lima orang teman, serta (e) bekerjanya terpacu oleh kompetisi. Ketika melompati tali karet, anak melakukan gerakan tubuh secara terkoordinasi untuk melatih kelenturan, keseimbangan, dan kelincahan. Permainan ini memiliki aturan-aturan yang mesti dipahami anak sehingga terstimulasi melakukan permainan fisik dengan aturan. Melalui aturan-aturan dalam bermain, anak memperlihatkan kemampuan diri untuk menyesuaikan dengan situasi dan tahu akan haknya.

Permainan marampera membantu anak terstimulasi untuk senantiasa mentaati aturan dalam bermain yang pada gilirannya anak akan memahami aturan kelas. Hal ini merangsang anak untuk bisa mengatur diri sendiri dan bertanggung jawab atas perilakunya untuk kebaikan diri sendiri, dengan demikian, anak mampu bermain dengan teman sebayanya, menghargai hak/pendapat orang lain, dan bersikap kooperatif dengan teman, serta dapat mengekspresikan emosi yang sesuai dengan kondisi yang ada (senang, sedih, antusias, dan sebagainya). Hal ini sejalan dengan pendapat Carolyn Triyon dan J. W. Lilienthal dalam Moeslichatun (2004), bahwa tugas perkembangan masa kanak awal di antaranya belajar bergaul dengan anak lain yang dapat menghasilkan dampak tanggapan positif dari anak lain. Selain itu, dapat mengembangkan perasaan positif dalam berhubungan dengan lingkungan, seperti mengembangkan rasa kasih sayang terhadap orang dan benda di sekitar.

Dari capaian perkembangan anak terhadap permainan tradisional Suku Batak Toba, terlihat capaian perkembangan anak memiliki rata-rata sama untuk ketiga jenis permainan, baik nilai pre-test $(2,4)$ maupun post-test $(2,7)$, meskipun capaian setiap anak berbeda-beda.

\section{PENUTUP}

\section{Kesimpulan}

Dari hasil analisis terhadap penelitian dapat disimpulkan bahwa capaian perkembangan anak memiliki rata-rata sama untuk ketiga jenis permainan, baik nilai pre-test $(2,4)$ maupun post-test $(2,7)$, meskipun capaian setiap anak berbeda-beda. Terdapat perbedaan yang signifikan nilai yang diperoleh peserta didik sebelum dengan sesudah melaksanakan permainan tradisional Suku Batak
Toba pada taraf signifikansi $5 \%$ terlihat dari nilai $\mathrm{t}>\mathrm{t} \quad(10,34>2,11)$. Permainan tradisional Suku Batak Toba dapat menstimulasi perkembangan fisikmotorik dan sosial-emosional anak usia 5-6 tahun.

Pertama, melatih otot kaki dan tulang punggung anak sehingga dapat melakukan gerakan tubuh secara terkoordinasi untuk melatih kelenturan, keseimbangan, dan kelincahan.

Kedua, memberi alternatif pilihan dalam 
menggendong atau memikul benda yang berat, menggunakan tangan kanan atau kiri secara bergantian yang bertujuan agar anak terampil menggunakan tangan kanan dan kiri. Hal ini memperlihatkan kemampuan diri untuk menyesuaikan dengan situasi.

Ketiga, anak terbiasa melakukan permainan fisik dengan aturan. Melalui aturan-aturan dalam bermain, anak memperlihatkan kemampuan diri untuk menyesuaikan dengan situasi dan tahu akan haknya sehingga terstimulasi untuk menaati aturan main dan hal ini membiasakan anak untuk menaati aturan kelas. Anak akan bertanggung jawab atas perilakunya untuk kebaikan diri sendiri dan bermain dengan teman sebayanya. Anak menunjukkan kemampuan dirinya untuk menyesuaikan dengan situasi pada saat menunggu giliran bermain dan kesalahan dalam aturan main.
Keempat, menstimulasi perilaku anak untuk menghargai hak/pendapat orang lain dan bersikap kooperatif dengan teman sehingga anak mengenal perasaan sendiri dan dapat mengekspresikan emosi yang sesuai dengan kondisi yang ada (senangsedih-antusias dsb), serta mengelolanya secara wajar (mengendalikan diri secara wajar).

Kelima, anak belajar untuk memahami bahwa setiap perbuatan memiliki konsekuensi atau akibat. Anak yang mendapat giliran main mengetahui akan haknya untuk melakukan giliran main.

\section{Saran}

Perlu dilakukan penelitian lebih Ianjut mengenai stimulasi perkembangan anak melalui permainan tradisional suku Batak Toba yang difokuskan pada aspek perkembangan lainnya seperti nilai agama dan moral, kognitif, bahasa, serta seni.

\section{DAFTAR PUSTAKA}

Kementerian Pendidikan dan Kebudayaan. (2014). Permendikbud RI No. 137 Tahun 2014 tentang Standar nasional pendidikan anak usia dini. Jakarta.

Kementerian Pendidikan dan Kebudayaan. (2014). Permendikbud RI No. 146 Tahun 2014 tentang Kurikulum pendidikan anak usia dini tahun 2013. Jakarta.

Departemen Pendidikan Nasional. (2003). UndangUndang Republik Indonesia No. 20 tentang Sistem pendidikan nasional. Jakarta : Madya Duta.
Moeslichatoen. (2004). Metode pengajaran di taman kanak-kanak. Jakarta: Rineka Cipta.

Montolalu, B.E.F. (2010). Bermain dan permainan anaka. Jakarta: Universitas Terbuka.

Mulyani, Y., \& Gracinia, J. (2005). Belajar di rumah untuk anak usia pra sekolah. Jakarta: Gramedia.

Russ S.W. (2004). Play in child development and psychotherapy. New Jersey: Lawrence Erlbaum Associates, Publisher.

Sudono, A. (2000). Sumber belajar dan alat permainan. Jakarta: Gramedia. 